\title{
Creating Cinderella? The Unintended Consequences of the Women Peace and Security Agenda for E U's Mediation Architecture
}

\author{
Toni Haastrup
}

School of Politics and International Relations, Rutherford College, University of Kent, Canterbury, CT2 $7 \mathrm{NX}$, United Kingdom

t.haastrup@kent.ac.uk

Received 7 June 2017; accepted 19 November 2017

\begin{abstract}
In 2000, the United Nations (UN) launched the Women, Peace and Security (WPS) agenda by adopting Security Council Resolution 1325. The agenda, among other things, called for the greater inclusion of women in peace negotiation practices and structures. While the European Union (EU) has made commitments to implementing the WPS agenda, the literature has not yet captured the institutional dynamics of the EU as it seeks to translate the WPS agenda into reality. This article takes stock of this hitherto excluded area of research. It argues that mediation is the 'Cinderella' of the Eu's peace and security institution because it has been ignored as a site for the implementation of the WPS agenda with important implications. Using a feminist institutionalist framework, the article shows the ways in which institutional practices of change aimed at including the new perspectives prompted by the WPS agenda lead to unintended gendered consequences.
\end{abstract}

* Toni Haastrup is Lecturer in international security and a Deputy Director of the Global Europe Centre at the University of Kent. Her current research interests center on the gender dynamics and processes of institutional transformation within regional security institutions. 


\section{Keywords}

EU - feminist institutionalism - mediation - UNSCR 1325 - WPS agenda - external relations

The European Union (EU) now has a well-established peace and security apparatus: the European External Action Service (EEAS), tasked with implementing and promoting the EU's vision of global peace and security. ${ }^{1}$ As a political actor whose identity is defined by its claim to be a peace project, one of its core aims requires the dissolution of conflict and, at best, conflict prevention and peacebuilding. It is unsurprising then that mediation is now considered an important tool of this European understanding of public diplomacy for peace and security. As part of this process of adopting new instruments, and thus (re)constituting new institutions for peacemaking, the $\mathrm{EU}$ has also committed itself to genderbased inclusivity in all aspects of its public policies, including its external security relations.

Like many other political entities, the Eu's primary means of including gender in security structures and their practices is through its commitment to the principles and aims of the United Nations' Women, Peace and Security (WPS) agenda. By practices, I refer to the everyday activities of those that work within and on behalf of the EU. Consequently, there is a normative legal framework that creates a context for the actual performances of EU agents. As a normative framework, the WPS agenda seeks to ensure that security actors prioritize gender inclusivity within their peace and security mechanisms and practices. Moreover, it seeks to position women especially as agents of positive change, while also acknowledging the implications of their particular experiences for the realization of peace and security.

The desire to implement the wPS agenda is unsurprising. From its foundational documents, the EU has sought to achieve gender equality (European Commission 2007). Moreover, as the EU has evolved, its desire to include gender equality initiatives into all of its policy areas has been articulated in its policy documents, most recently in the Gender Action Plan 2016-2020, and also confirmed in academic literature (Pollack \& Hafner-Burton 2000, 2010;

1 I am grateful to members of the $\mathrm{EU}$ as International Mediator Collaborative Research Network (https://euaimblog.wordpress.com/) for stimulating discussions and previous comments and feedback on earlier drafts of this article. I am also grateful to UACES for providing funding to facilitate these discussions. 
Allwood 2014). While the EU's commitment to the inclusion of gender equality initiatives through the strategy of mainstreaming is debated, it is nevertheless an embedded legal and normative principle (Guerrina 2005; Kantola 2010; David \& Guerrina 2013). Yet, the intersection of this legal/normative principle of gender inclusivity beyond its militarized iterations of what constitutes peace and security remains relatively understudied in general—especially as it pertains to the $\mathrm{EU}$.

In this article, I explore the extent to which, and how, the global wPS agenda, facilitated by the United Nations Security Council Resolution (UNSCR) 1325 , is being advanced within the EU's external peace and security architecture. I focus on the institutional practices that enable the EU's role as a security actor, particularly in international mediation. While more recent research has focused on the mediation and negotiation processes themselves, the institutions that support these processes tend to be ignored (Davis 2014). Yet, political institutions structure human interactions and are thus important to understanding outcomes (North 1990:3).

This article is concerned with how the EU interprets and adapts the wPS agenda internally. This internal insight will undoubtedly impact the Eu's ability to facilitate more gender inclusive mediation practices and peace settlements. Feminist institutionalism as an analytical framework are used to assess the implications of formal and informal rules, norms and practices that include, reject, alter or ignore gender inclusivity norms within the EU's mediation apparatus. ${ }^{2}$ In this context, the meaning of gender draws on the work of feminist IR scholar V. Spike Peterson who views gender as socially constructed and often dependent on the privileges or hierarchies and qualities ascribed to what is deemed masculine and what is deemed feminine (Peterson 2004). So, although gender does not equate to women, the treatment of women and their situation within the EU's security institution is essential to understanding how gender works in institutionalizing mediation. Further, the goal of gender inclusivity through sensitivity or awareness is to redress those existing gendered privileges and hierarchies, while acknowledging its effects on the subordination of women.

For this analysis, the official documents of the EU that focus on security, gender strategies, the EU's mediation capabilities, and the constitution of the Common Security and Defence Policy (CSDP) are relied on. The documents include official press releases, the implementation strategies for the WPS agenda,

2 This is similar to the approach taken by Allwood (2014) in her evaluation of gender mainstreaming in EU climate change policy. 
evaluation reports, Gender Action Plans and Road Maps. Official documents help to map out the official narratives of gender, while potentially also revealing the institutional contradictions that enable the persistence of gendered hierarchies.

The analysis also includes documents about the EU's mediation capabilities and efforts to implement the WPS agenda produced by third parties, especially civil society groups. Civil society reports and evaluations are useful for corroborating the rhetoric of actions, while also providing alternative narratives to the official ones. Finally, unstructured interviews and email exchanges with current and former EEAS policy practitioners and civil society representatives are employed. These interviews are essential to understanding the experiences of those tasked with implementing the wPS agenda within and on behalf of the EU. The narratives or stories of agents highlight the practices that produce and reproduce gender even through the process of implementing a gendersensitive or gender-aware security framework. In this way, the analysis identifies the ways that agents interact with formal frameworks that are intended to institutionalize new norms to enable the process of change.

This investigation is necessary for a few reasons. First, since mediation by its nature strives to create an environment of inclusivity (Spencer 2004; Girke 2015) and has the potential to dismantle hierarchies, the extent to which the EU can be an international mediator is of both intellectual and policy relevance. Second, the EU's mediation capabilities are relatively new in the context of its peace and security institution and external relations' practices. This analysis provides the opportunity to assess the extent to which new institutional practices can open up the space for norms to become embedded within institutions. Finally, whereas the EU claims that part of its identity is to be an actor that promotes gender equality (European Commission 2015), this assessment aims to unveil the opportunities and constraints for the eventual implementation of this claim as part of its external relations.

\section{The Eu, Gender, Peace and Security}

The EU has a long history of acting in the area of international conflict mediation; this is an important part of its foreign policy or external security practice of conflict transformation and resolution, although often a secondary capacity when compared to its other international roles (Interviewee G 2017). Yet, in spite of the EU's roles in international mediation practice, the nature of what it does has remained understudied and until recently unacknowledged in most scholarly work. 
To a large extent, this is due to the fact that compared to other areas of foreign and security policy, practitioners within the institution do not take the EU's role in mediation security policy as seriously. It was not until the public acknowledgement of $\mathrm{EU}$ aspirations and competencies in the area via the 2009 Concept that mediation came to the fore as an area of importance for better understanding the range of $\mathrm{EU}$ foreign policy practices.

Given the relatively limited accounts of the EU and its international mediation roles, it is not surprising that, to date, a reflection on the gendered dimensions of the structures within which these roles are developed has not been undertaken. Yet, the drive to gain knowledge about how security institutions adopt new global gender norms demands that we critically engage with the ways in which this applies to the EU. Moreover, assessing the EU's adoption of the WPS agenda within its mediation capabilities provides insight into the regional (meso) dimensions often ignored in favor of global or national level analysis.

As a first step to gaining this knowledge, the question of how the institutional environment of the EU facilitates correctives to the gendered deficiencies in the EU polity's ability to mediate internationally is essential. A qualitative reflection on some of the issues arising from the EU's mediation capabilities and practices may then signal to the continued relevance of the Eu's role as a global gender actor and peacemaker.

The discourse that links gender to peace and security within the EU is, of course, directly linked to its commitment to the implementation and promotion of the WPS agenda. The WPS agenda is where, to an extent, some of the feminist concerns about the gendered nature of international security have been recognized so far. The WPS agenda was driven by the acknowledgement that despite the unique experiences of women during periods of insecurity, especially armed conflict, the predominant security interventions enacted by global security actors were often only reflective of men's experiences. While this is a narrow understanding of gender and how it interacts with security, it has been considered a useful starting point (Pratt \& Richter-Devroe 2011; Shepherd 2010).

Starting with the first resolution (1325) in 2000, there have been seven other resolutions that have sought to clarify and deepen the WPS program (Kirby \& Shepherd 2016). Relating to mediation in peace and security practice, UNSCR 1325 reaffirms:

the important role of women in the prevention and resolution of conflicts and in peace-building, and [stresses] the importance of their equal participation and full involvement in all efforts for the maintenance and 
promotion of peace and security, and the need to increase their role in decision-making with regards to conflict prevention and resolution (s/Res/1325-2000).

The resolution goes on to argue that the differentiated impact of conflict on women requires that interventions acknowledge their experiences and incorporate these into responses to conflict-based insecurity. Further, the resolution advocates for the inclusion of women during peace processes (including mediation and negotiation) as part of a broader strategy of women becoming more visible and playing more instrumental roles in international diplomacy through senior positions like special envoys (s/Res/1325).

In UNSCR 2122 (2013) especially, the theme of women's participation in peace processes like mediation comes up again as essential to the WPS agenda's broader aims of gender inclusivity. It called on the UN Secretary General:

to strengthen the knowledge of negotiating delegations to peace talks, and members of mediation support teams, on the gender dimensions of peacebuilding, by making gender expertise and gender experts available to all United Nations mediation teams (s/Res/2122-2013).

Implicitly or explicitly, all the resolutions call for the security mechanisms to be spaces in which gender inclusivity thrives and is supported.

Much of the narrative around the WPS agenda is derived from the presumption that persistent underrepresentation of women contributes to an overtly masculine environment (Kronsell 2016a, 2016b). This presumption needs to be addressed. How women are positioned within institutions of peace and security constitutes an important cornerstone for a broader understanding of gender in international mediation practices.

Research has consistently shown that women are not only systematically excluded materially from participation in formal and semi-formal mediation processes, negotiations, and dialogue (Lockett 2008; Mwai 2008), but often also excluded from the stories we tell about mediation processes. For the most part, peace diplomacy in theory and practice continues to be dominated by a gender-blind approach that renders women and their experiences almost invisible, while privileging male bodies and experiences.

Women's perspectives on gender-specific justice are, for example, often erased from final peace agreements - the inevitable outcome of these gendered structures. While it is worth reiterating here that women are not synonymous with gender, the exclusion of women within the mediation process and their outcomes is indicative of problematic gendered hierarchies (UN Women 
2012). The mediation environment is a site where hegemonic masculinities prevail (Aggestam \& Svensson 2017). By examining the institutionalization process of gender norms, this article gets to the root of some of the outcomes observed concerning the exclusion of women in mediation practice.

For the EU, the WPS agenda maps gender inclusion on to the broader aims of the polity as a proponent of gender inclusivity. The EU views the promotion of equality as part of its core identity as a political actor (MacRae 2010). Drawing on primary institutional documents, MacRae $(2006,2010)$ effectively shows that the EU institutions in Brussels as well as the member states have consistently sought to uphold gender equality as a fundamental value of the EU through formal legal provisions. For example, the Treaty of Amsterdam in 1997 required the EU to consider the inclusion of gender perspectives in all of its policy areas. Ten years later, the Lisbon Treaty (2007) reiterated this commitment to gender equality as a priority of the $\mathrm{EU}$ in how it executes all of its policies. In between these two constitutional documents, numerous EU legislations and directives have affirmed the importance of equality between men and women within the EU (European Union 2015; European Commission 2015). The EU has sought to implement programs aimed at ensuring this identity. And, given that the EU is often amenable to adopting UN rights-based frameworks, the establishment of the WPS agenda in 2000 gave the EU access to a framework that can be adapted for gender inclusivity in international peace and security matters.

As the intersection of gender and security evolved globally, and soon regionally and nationally, so did the EU's own apparatus for peace and security, which emphasized the development of what is now termed the Common Security and Defence Policy (CSDP). The CSDP is the EU's framework for 'hard security' (Posen 2004, 2006). Of course, when compared to other security actors, most notably the United States, some have balked at the idea of the EU possessing hard power, even through the CSDP (Gross \& Menon 2013). But, to an extent, this is the intent of the CSDP as evidenced by the 2017 European Security and Defence Package (EEAS 2017).

The CSDP fully embodies and represents the hegemonic masculinity within the peace and security institution. This masculinized security is then juxtaposed against non-militarized forms of conflict transformation/resolution that are perceived as feminized (Puechguirbal 2012; Stern 2011).

The concurrent evolution of the WPS agenda and CSDP has had implications for how gender is understood and adapted within the broader Eu peace and security institution. This, in turn, has had repercussions for the inclusion of gender within the EU's nascent mediation architecture. In the next section, the ways in which the EU has sought to institutionalize gender concerns as an 
intentional process of transformation are outlined, simultaneously exposing its unintentional gendered consequences.

\section{Gendering EU Security: A Feminist Institutionalist Approach}

To understand the treatment of gender in the context of EU's mediation capabilities, one must first understand the initial entry of gender perspectives into the broader peace and security institution.

New institutionalist approaches have been useful in analyzing how norms become included within the EU (Haastrup \& Kenny 2016). Institutions are defined here as 'rules of the game' (North 1990: 3) which include codified frameworks and informal practices. This definition of institutions can help underscore the opportunities and constraints faced in the process of including the gender inclusivity norm in security as framed by adherence to the WPS agenda. Rules are defined as "prescriptions that define what actions (or outcomes) are required, prohibited or permitted and the sanctions authorized if rules are not followed" (Ostrom et al. 1994: 38).

The institutional story of peace and security in the Eu highlights 1999 as an important year due to the establishment of the European Security and Defence Policy (ESDP). Further, in 2003, the EU deployed its first military mission, another critical moment in its development as a peace and security actor. These key moments, and the specific activities attached to them, have had implications for the current development of gender within the EU's security institution. To better unpack this, I rely on feminist approaches to new institutionalism or feminist institutionalism (FI).

FI (MacKay, Monro \& Waylen 2009; Chappell \& Waylen, 2013; Waylen 2014) emphasizes institutions as a key site of gendered interactions and pays attention to the ways in which women are included in political processes. When feminists seek to use new institutionalist approaches, they pay attention to the distribution of power within institutions, as well as the constraining effect this may have on the inclusion of intended (positive) norms aimed at change. Institutions, for feminists, tend to reproduce the gender differences and hierarchies found in society. Institutions, for FI analysis, are thus not neutral. This approach further helps to investigate the ongoing interplay of masculinities and femininities. These are enduring features that have further implications for the ways in which gender becomes understood and prioritized (Acker 1992).

Feminist approaches to institutionalism pay special attention to the impact of informal yet routinized practices, and their ability to disrupt the objectives of formal rules. FI underscores the role that specific individuals or interest 
groups play within a given institutional context. This recognition of agents' roles is significant because, through a deepened engagement with those in a position to enable change, we can better observe the opportunities and constraints of the institution to accept new rules, norms and practices of gender inclusivity. Moreover, feminist analysis can, in the long run, help to problematize the locations of power in gendered institutions. Finally, FI approaches allow us to unpack the contestation in meaning of the interaction of gender and security within the EU and its impact on the EU's mediation capabilities.

Some scholars have argued that the inclusion of gender perspectives in areas of EU policymaking has been possible due to the existence of 'velvet triangles.' Velvet triangles are used by Woodward (2003) to refer to 'femocrats': individuals positioned within a bureaucratic structure who are motivated to work towards transformative change in line with feminist goals, civil society organizations, and epistemic communities (Guerrina \& Wright 2016: 296).

However, they also suggest that this has not been the case for EEAS in general and not mediation specifically. As Guerrina and Wright (2016: 297) highlight, the systematic inclusion of equality perspectives in EU policymaking has depended especially on femocrats within the European Commission. As policy entrepreneurs, their unique roles within formal structures ensured that gender (equality) was kept on the agenda. Of course, the advocacy of civil society coalitions like the European Women's Lobby (EWL) and epistemic communities like the FEMM Committee on Women's Rights and Gender Equality in the European Parliament helped to ensure implementation as well (Guerrina \& Wright 2016: 297). However, there is no such coalition working together in the context of the EEAS and consequently peace and security in the EU.

The inability of the velvet triangle to coalesce around peace and security within the EU can be explained in part by the fact that this area is still difficult for civil society to penetrate. As Guerrina and Wright (2016: 298) show, although the EWL would seem to be the logical choice for one point of the triangle, the non-feminist European Peacebuilding Liaison Office (EPLO) replaces it in this context. And while both organizations have been involved with the informal task force on the implementation of UNSCR 1325, there is no active cooperation for lobbying the security institution. Although EPLO facilitates a working group on the WPS agenda, their focus is primarily to monitor EU member states' National Action Plans (NAP) rather than ensuring the institutional dynamics that allow the WPS agenda to thrive within the EU. Importantly, EPLO is not driven by a feminist ethos; any interest in the EU's internalization of the WPS agenda is simply functional. Moreover, there are those within the Eu's peace and security apparatus that remain resistant to 
integrating gender perspectives. As one interviewee noted "what I have felt ... is a lack of understanding and lack of commitment ... there are probably a few people who are hostile to this" (Interviewee D 2017). Finally, the fact that the CSDP remains intergovernmental is a further disadvantage to crafting a coherent approach for advocacy by civil society organizations.

Despite the seeming lack of a coherent approach, some of the interviews conducted for this article suggest that, although a velvet triangle was unable to coalesce to influence the EEAs's work, there were key individuals who advocated for the inclusion of gender, especially within the CSDP, using the WPS framework and existing Union provisions (Interviewee A 2016; Interviewee B 2016; Interviewee E 2017; Interviewee G 2017). These femocrats include individuals who lobby for resources to go into gender inclusive activities and advocate for gender mainstreaming in peace and security. They also include those who evaluate specific projects from a gender perspective. These individuals are otherwise known as gender focal points (GFPS). One consultant who has been engaged in the institutional review of the inclusion of gender perspectives in the EU noted that "[GFPs] will really go out of their way to look for resources to ensure that there are programs, to develop their capacity, [and] to share their experience with others who are working in a similar field" (Gya 2011: 10).

For these femocrats however, their focus on the implementation of the WPS agenda has been the CSDP where each attempt was program- or missiondependent. And while the competencies of the EEAs extend beyond the 'hard security' of the CSDP, it has been the main entry point for the WPS agenda in the $\mathrm{EU}$ (Interviewee $\mathrm{G}$ 2017). The inclusion of gender perspectives in the CSDP has been driven primarily by two concerns: the first is the EU's obligation to promote human rights as a core value (Interviewee C 2017) and the second involves the efficiency of the mission (Interviewee A 2016; Interviewee B 2016; Interviewee D 2017). Gender mainstreaming, in particular, is viewed as instrumental to other aims.

Concerning the first obligation, it is not at all surprising that the EU seeks to maintain its legitimacy as an international actor and to its own constituents as acting in the best interests of human rights. For example, the EU Strategic Framework and Action Plan on Human Rights and Democracy (2012) requires the implementation of human rights and gender equality. It views the operationalization of the Comprehensive approach to the $\mathrm{EU}$ implementation of the United Nations Security Council Resolutions 1325 and 1820 on women, peace and security (2008) as a human rights duty. Further, many of those driving the WPS agenda within the EEAS are often double-hatted in another role that is often human rights related. 
Beyond this, gender inclusivity within the security domain by those who champion it is also a matter of mission efficiency. The idea is that if gender perspectives, viewed as the perspectives of $50 \%$ of the population, are not considered in the EU's external security work, the success of the EU in bringing peace to a particular region will be challenged. Consequently, operational effectiveness requires the inclusion of gender perspectives in planning to ensure that all aspects are considered (Groothedde 2013). The notion that women should be included is however premised upon essentialist understandings of what women's roles in conflict (and its transformation or resolution) can be. As suggested by a Spanish member of the EU Military Staff, "the $50 \%$ of the population [has] usually a greater sense of protection of the family as the group unit of society" (Pardo Martinez 2015). The implication of this is that while engaging women as part of the Eu's security processes is positive, it also showcases a very narrow view of women's roles, that is, preserving the family.

This narrative is effectively essentializing and instrumentalizing women through their potential motherhood. This approach, in addition to the seeming separation of GFPs from systematically including gender in the work of the EEAS, has been rightly criticized. By all counts, the area of mediation is not excluded from this. It reifies and re-entrenches traditional gender roles, pushing women again into the background. Moreover, even within this domain where the EU has shown a clear preference for 'promoting gender,' there remains a lot of resistance: "[...] all the people who plan EU missions are all ex-military or military people, hard security people and they all believe that thinking about gender and human rights is a joke, a waste of their time" (Interviewee G 2017).

Some institutional innovation has taken place through the creation of the office of the EEAS Principal Advisor on Gender and the Implementation of UNSCR 1325, Women Peace and Security. In this role, the officeholder reports to the Secretary General of the EEAS and not directly to the High Representative. And while this office is intended to work closely with all aspects of peace and security, including mediation, it does not have jurisdiction over the various structures that make up this institution. Furthermore, anecdotally, there are concerns that this role does not hold enough gravitas to accomplish a substantive institutional change that pushes the WPS agenda significantly. The extent to which this office, by its simple existence, can affect any sort of change is thus highly questioned.

To an extent, the focus on women which inadvertently essentializes their roles in peace and security has been a shortcoming of numerous resolutions 
that constitute the WPS agenda. With regards to mediation specifically, essentializing women has also meant a framing of women as innately peaceful. While seemingly positive, it actually limits the possibilities of women's roles in peace and security, further subordinating them. Feminists have long debunked this myth of more empathy from women (Elshtain 1987; Sjoberg \& Gentry 2007); thus, this is a problematic frame for gender inclusivity. While the participation of women in field operations or 'hard security' may be essential to gendering the militarized domain of CSDP, the cross-cutting nature of gender, in feminist terms, is missed with this overtly instrumental focus (MakiRahkola \& Suhonen 2014). However, this essentializing of women is often used as leverage for the initial recruitment of women and the inclusion of women's perspectives and experiences within the mediation apparatus. And yet, the increased recruitment of women or the inclusion of women's perspectives and experiences have not been observed when it comes to the makeup of the EU's mediation personnel or priorities.

Several scholars have already noted that the attempt to include the various aspects of the WPS agenda in the EU has been a difficult process (Kronsell 2012; Guerrina \& Wright 2016). The interviews cited within this article all confirm this. The security apparatus still has a tendency to be resistant to the efforts of inclusion (Interviewee D 2017; Interviewee E 2017; Interviewee F 2017).

The institutional directory of the EEAS as of 16 May 2017 also appears to confirm this resistance. There are 57 personnel who have leadership or decision-making positions within the General Secretariat, the Office of the Deputy Secretary General CSDP and Crisis Response, and the EU Military Staff. Of those, only 11 are women. This includes the High Representative and the Secretary General and numbers within the unit responsible for mediation, Prevention of conflicts, Rule of law/ssR, Integrated approach, Stabilisation and Mediation (PRISM).

In this sense, the institutional environment constrains the inclusion of new norms. Further, despite the existence of GFPs, the EU still lacks the capabilities for ensuring gender inclusivity in its institutions in a number of ways. The individuals who act as focal points are often only in this post in a part-time capacity and there is still a limited number of them (Gya 2011). Given the tendency of the EU to shuffle staff around, those championing gender inclusivity may not have staying power to see that gender norms take hold.

It is in this complex environment that the EU's mediation architecture functions. What we find is that within this environment, despite some general innovations in peace and security, they have had gendered consequences on the integration of gender perspectives for the Eu's mediation capabilities. 


\section{Mediation: A Gender, Peace and Security Cinderella Story?}

In adhering to the entreaties of the WPS agenda, but especially the first one, UNSCR 1325, the 2009 Concept on Mediation and Dialogue commits to promoting and supporting women's participation and gender inclusivity in mediation practices. The concept echoes the commitment to tackling the underrepresentation of women in peace processes and mediation, and also noted that mediation teams often lacked gender expertise, a condition the Concept aims to address.

Yet, three years after the Concept was first introduced, one report concluded that "women remain systematically and very significantly under-represented" (EEAS 2012: 1). This seems counterintuitive to an institution that believes the implementation of the WPS agenda is essential to its evolving security architecture. Furthermore, the integration of gender in mediation could be assumed to be relatively uncontroversial since this is a 'soft' security area (Interviewee $\mathrm{G}$ 2017). Yet, this is not the case. It would seem then that mediation also suffers from the challenges that constrain the full application of the WPS agenda within the EU's peace and security institution.

Moreover, I would suggest that it is precisely because of the manner of gender inclusion in the 'hard' security area (CSDP) that gender inclusion in mediation has been relatively ignored. As historical institutionalist accounts emphasize, choices that are initially made at critical moments have a tendency to 'stick' (Aspinwall \& Schneider 2001: 10). These initial choices, like the one to focus almost exclusively on integrating gender in CSDP, take on a life of their own. In other words, the practices of gender inclusion in security have had unintended gendered consequences on mediation (Pierson 2004: 104).

While the existence of GFPs within the mediation structures suggests an interest in gendering mediation, this approach also means that gender can be seen as something distinctly different from mediation itself. It is something to be applied on a case-by-case basis rather than a systematic consideration in the practices of mediation both in Brussels and EU delegations. Indeed, in the EU delegations, the GFP is often responsible for other portfolios as well.

To further illustrate this abstraction, when I first approached a contact within the mediation unit about gender inclusivity, I was immediately directed to another colleague who was ostensibly known to work in the area of human rights and gender equality in all phases of CSDP missions. Unfortunately, this particular individual left this post almost five years ago! Indeed, a contact working within the Mediation Support Team was not aware of the GFP or the immediate relevance of gender in their day-to-day work practices.

What we find then is that while there are some femocrats around the peace and security institution in the context of the CSDP, this is absent from 
mediation. This is not to suggest that there is no one concerned with gender inclusivity; indeed it is quite the opposite and this has been confirmed by at least one interviewee external to the EU (Interviewee G 2017). However, the institutional set up through which mediation has existed, first within the conflict prevention, peacebuilding and mediation stream of the EEAS and now as part of PRISM, has not prioritized gender inclusivity.

Gender inclusion is discursively constructed as important, with a focus on the EU's tendency to promote the inclusion of women externally, especially among parties to a conflict. The focus has not been on building the capacity for such inclusion within the EU itself. Whereas many EEAS documents state the necessity of employing more women within the whole of the Eu's peace and security institution, the majority of those in mediating positions are men. The most obvious EU representatives to participate in mediations and dialogues are the Special Representatives (SR); yet, since the appointments to these posts began, only 3 out of $5^{0}$ appointments have been women. While it is worth noting that two High Representatives (HR) for Foreign and Security Policy have been women and have participated in various diplomatic negotiations, these are exceptions as the representation of women is not reflected at other mediation and dialogue levels. Indeed, the employment of women consecutively in this post has not actually increased the likelihood of gender inclusivity being on the agenda.

A key reason for the underrepresentation of women in mediation is that, unlike in other areas of the CSDP where some femocrats have been quite active, there are no advocates for more women in the top jobs of Special Representatives. This stands in contrast to the EU's rhetoric to external partners that including women in peace process negotiations is important for conflict prevention and lasting peace. It also stands in contrast to the idea of the EU as a gender actor. The focus on military/civilian-based CSDP missions has further emphasized the protection of women in the field, especially from sexual violence, as the priority of the EU's implementation of the WPS agenda. Inadvertently, this focus usurps another idea within the wPS that sees women as decision-makers, planners and active agents in negotiations and dialogue for peace. While the WPS agenda has grown to acknowledge that this early focus may have had some harmful implications for the positioning of women, the EU's core frameworks have yet to catch up. In examining mediation, then, the hegemonic masculinity of the EU's peace and security rules, norms and practices are significantly magnified by constructions of gender and how women are situated within the internal structures of the EU's external relations.

In conducting a feminist analysis of institutions, it becomes clear that institutional design and timing matter for the possibility of including new (gender) norms. But also, institutions are replete with problematic gendered dynamics 
(Acker 1992). And, of course, there is a tendency for institutions to persist or remain path-dependent. This means that it is difficult to make changes to them. In cases where change is seemingly apparent, the scope is potentially limited. Thus, for the EU, the decision to make the CSDP the primary site for gender inclusivity has been constraining. What is instead observed is the reproduction of gender hierarchies of the masculinized CSDP onto the feminized mediation institution. This is contrary to the proclaimed desire for inclusivity in the architecture of conflict prevention, in the transition towards post-conflict societies specifically, and in the Eu's peace and security institution as a whole. But this also exemplifies the unintended consequences of including new norms or rules within an institution.

\section{Conclusions}

This interrogation of the state of affairs of the EU's mediation architecture as part of the Eu's peace and security institution is essential because this is the medium through which the EU develops its relations with external third parties. In examining mediation specifically, the analysis has allowed for more criticality around who is included and excluded in the formation of what peace and security means, and what is prioritized within those means. Agents rely on formal frameworks and informal practices to push agendas through, intended to change the status quo. On the one hand, we see that the eu's peace and security institution has been resistant to the coalition of a velvet triangle; on the other hand, femocrats have been able to rally around the implementation of the WPS agenda in the context of the CSDP. This has had the impact of propelling the WPS agenda forward within the EU albeit with significant limits. Importantly, the analysis has helped us rethink and problematize certain practices intended to foster institutional transformation, but which actually reproduce problematic gendered dynamics.

In the EU's official narrative of how gender intersects with security, the initial application of the WPS agenda is uncritically accepted. This application, which emphasizes protection from sexual violence, is often used as an external tool in an effort to boost the EU's legitimacy and credentials as a gender/ security actor. Despite the commitments that permeate the official narratives of the $\mathrm{EU}$, there is more emphasis on promoting gender equality to the world without reflection on whether the EU practices what it preaches.

The EU's ability to be a robust actor in the domain of WPS will continue to be troubled by the lack of attention paid to the agents intended to implement 
the WPS agenda. Consequently, at the heart of gendering mediation is the need to internalize the agenda. Moreover, for the most part, the focus on the CSDP as the site for gender inclusion in EU security has also meant a focus on the protection element of the WPS agenda, which makes it easy to externalize.

This emphasis on protection tends to frame women as victims first (Muehlenhoff 2017). Externalized, women are victims of the conflict in which the EU has to intervene; they are victims of specific types of gendered violence; and they are victims of the communities to which they belong in this framing. This, however, does not fit within an internal EU narrative that already accepts gender equality in which women are agents, not victims. Consequently, it has become even more difficult for the WPS agenda to be internalized within mediation.

Finally, the EU's capacities in mediation as situated within the EEAS are still unsettled. When it was formally launched, it was under the ambit of Security Policy and Conflict Prevention, as part of the conflict prevention, peacebuilding and mediation stream. This has now been dissolved and mediation has reconstituted within PRISM. The unsettledness of mediation among the more traditional security instruments makes inexpedient the meeting of WPS aspirations and evaluating institutionalization internally.

The institutional framework through which the Eu's mediation capabilities were developed continues to exclude women as agents of change or active security actors. This current situation is illustrative of the dominance of hegemonic masculinity within the EU's security institutions. It is also reflective of how, despite formal provisions for inclusions, informal practices of individuals who reject gender perspectives or leave it as a side concern impact the potential transformation of institutions. Ultimately, this reflects negatively on the priorities of the institution. In the future, gendering mediation as an activity of the EU within this environment will at best be ad-hoc.

\section{References}

Abbnik, J. (2006). "Discomfiture of Democracy? The 2005 Election Crisis in Ethiopia and its Aftermath." African Affairs 105, 419: 173-199.

Acker, Joan (1992). "From Sex Roles to Gendered Institutions." Contemporary Sociology 21, 5: 565-569.

Aggestam, K. and I. Svensson (2017). "Where are the women in peace mediation? (2017)," in K. Aggestam and A. Towns, editors, Gendering Diplomacy and International Negotiation. Basingstoke: Palgrave Macmillan. 
Allwood, Gill (2014). "Gender mainstreaming and EU climate change policy," in E. Weiner and H. MacRae, editors, The Persistent Invisibility of Gender in EU Policy. European Integration Online Papers, Special Issue 1, 18: 1-26.

Aspinwall, M. and G. Schneider (2001). "Institutional Research on the European Union: Mapping the Field," in G. Schneider and M. Aspinwall, editors, The Rules of Integration: Institutionalist Approaches to the Study of Europe. Manchester: Manchester University Press.

Babaud, S. and J. Ndung'u (n.d.). Early Warning and Conflict: Prevention by the EU: Learning Lessons from the 2008 Post-election Violence in Kenya. Brussels: Initiative for Peacebuilding.

Chappell, L. and G. Waylen (2013). "Gender and the Hidden Life of Institutions." Public Administration, 91, 3: 599-615.

Council of the European Union (2008). Comprehensive Approach to the EU Implementation of the United Nations Security Council Resolutions 1325 and 1820 on Women, Peace and Security. Brussels: Council of the European Union. Available at: https://www.consilium.europa.eu/ueDocs/cms_Data/docs/hr/news187.pdf.

Council of the European Union (2010). Communication: Lessons and Best Practices of Mainstreaming Human Rights and Gender into CSDP Military Operations and Civilian Missions. 17138/1/10 REV 1. November 30.

Council of the European Union (2012). EU Strategic Framework and Action Plan on Human Rights and Democracy. Brussels: Council of the European Union.

David, M. and R. Guerrina (2013). "Gender and European External Relations: Dominant Discourses and Unintended Consequences of Gender Mainstreaming." Women Studies International Forum 39: 53-62.

Davis, Laura (2014). EU Foreign Policy, Transitional Justice and Mediation: Principles, Policy, and Practice. London: Routledge.

Elshtain, Jean Bethke (1987). Women and War. New York: Basic Books.

European Commission (2007). “5o Years Gender Equality Law." Press Release, мемо 07-426. Available at: http://europa.eu/rapid/press-release_MEMO-07-426_en.htm.

European Commission (2015). Strategic Engagement for Gender Equality: 2016-2019. Brussels: European Union.

European Commission (2016). Gender Action Plan 2016-2020. Brussels: European Union. European External Action Service (2017). "The Defence Package: Fact Sheet." Available at: https://eeas.europa.eu/sites/eeas/files/defence_package_04_07_2017.pdf.

European Union (2013). Commission Staff Working Document: Midterm Review of the Strategy for Equality between Women and Men (2010-2015). Brussels: European Union.

Girke, Natalie C. (2015). "A matter of balance: the European Union as a mediator in Yemen." European Security 24, 4: 509-524. 
Groothedde, Stephanie (2013). Gender Makes Sense: A Way to Improve Your Mission. The Hague: Civil-Military Centre of Excellence.

Gross, E. and A. Menon (2013). "CSDP: Between internal constraints and external challenges." Issue Reports 17. Paris: E U Institute for Security Studies.

Guerrina, R. and K. A. Wright (2016). "Gendering Normative Power Europe: Lessons of the Women, Peace and Security agenda." International Affairs 92, 2: 293-312.

Gya, Giji (2011). Women Peace and Security in EU Common Security and Defence Policy. Brussels: Civil Society Dialogue Network.

Haastrup, T. and M. Kenny (2016). "Gendering Institutionalism: A Feminist Institutionalist Approach to EU Integration Theory," in G. Abels and H. MacRae, editors, Gendering European Integration Theory: Engaging New Dialogues. Berlin: Barbara Budrich Publishers.

Hazelzet, Hadewych (2013). "Gender and European Union's Common Security and Defense Policy." Gender Violence in Armed Conflicts 11: 137-147.

Interviewee A (2016). "European Council Official with Foreign Policy Portfolio." March 1 (Female).

Interviewee B (2016). "EEAS Official in Geneva." March 2 (Female).

Interviewee C (2017). "EEAS Official in Brussels in leadership position." March 8 (Female).

Interviewee D (2017). "EEAS Official affiliated to external mission in former conflict zone." March 20 (Male).

Interviewee E (2017). "EEAS Official affiliated to external mission in conflict zone." March 15 (Male).

Interviewee F (2017). "Former EEAS crisis management civilian in leadership position." March 3 (Male).

Interviewee G (2017). "Co-Director at a Brussels-based civil society organization." May 23 (Female).

Kantola, Johanna (2010). Gender and the European Union. Basingstoke: Palgrave Macmillan.

Kirby, P. and L. J. Shepherd (2016). "Reintroducing women, peace and security." International Affairs 92, 2: 249-254.

Kronsell, Annica (2012). Gender, Sex and the Postnational Defense. Militarism and Peacekeeping. Oxford: Oxford University Press.

Kronsell, Annica (2016a). "The Power of EU Masculinities: A Feminist Contribution to European Integration Theory." JCMS: Journal of Common Market Studies 54, 1: 104-120

Kronsell, Annica (2016b). "Sexed Bodies and Military Institutions: Gender Path Dependency in EU's Common Security and Defense Policy?" Men and Masculinities 19, 3: 311-336. 
Lockett, Kathryn (2008). “The Mechanisms of Exclusion: Women in Conflict.” Feminist Legal Studies 16, 3: 369-376.

Mackay, F., M. Kenny, and L. Chappell (2010). "New Institutionalism through a Gender Lens: Towards a Feminist Institutionalism?" International Political Science Review 31, 5: 573-588.

Mackay, F., S. Monro, and G. Waylen, (2009). "The Feminist Potential of Sociological Institutionalism." Politics \& Gender 5, 2: 253.

MacRae, Heather (2006). "Rescaling Gender Relations; the Influence of European Directives on the German Gender Regime." Social Politics: International Studies in Gender State \& Society 13, 4: 522-550.

MacRae, Heather (2010). "The EU as a Gender Equal Polity: Myths and Realities." Journal of Common Market Studies 48, 1: 155-174.

Mäki-Rahkola, A. and J. Suhonen (2014). "Gendered Civilian Crisis Management: Troubleshooting CSDP Missions.” CMC Finland Peacebuilding and Civilian Crisis Management Studies 5, 1: 8-33.

Muehlenhoff, Hanna L. (2017). "Victims, soldiers, peacemakers and caretakers: the neoliberal constitution of women in the EU's security policy." International Feminist Journal of Politics 19, 2: 153-167.

Mwai, Elizabeth (2008). "Women Decry Expulsion from Mediation Talks." Human Rights House. January 30. Available at: http://humanrightshouse.org/noop/page .php? $\mathrm{p}=$ Articles $/ 8491 . h \mathrm{tml} \&$ print $=1 \& \mathrm{~d}=1$.

North, Douglass C. (1990). Institutions, Institutional Change and Economic Performance. Cambridge: Cambridge University Press.

Ostrom, E., R. Gardner and J. Walker (1994). Rules and Common Pool Resources. Ann Arbor, MI: University of Michigan Press.

Pardo Martinez, Alfredo (2015). The Implementation of the Gender Perspective in the EU Civilian and Military Missions: Leadership Wanted. Security Policy Brief 67, Brussels: Royal Institute for International Relations.

Peterson, V. Spike (2004). "Feminist Theories within, Invisible to, and beyond IR." The Brown Journal of World Affairs X, 2: 35-46.

Pierson, Paul (2004). Politics in Time: History, Institutions, and SocialAnalysis. Princeton, NJ: Princeton University Press.

Pollock, M. and E. Hafner-Burton (2000). "Mainstreaming Gender in the European Union." Journal of European Public Policy 7, 3: 432-56.

Pollock, M. and E. Hafner-Burton (2010). "Mainstreaming international governance: The environment, gender, and IO performance in the European Union." Review of International Organizations 5, 3: 285-313.

Posen, Barry (2004). "ESDP and the Structure of World Power." The International Spectator, XXXIX: $5^{-17}$. 
Posen, Barry (2006). "European Union Security and Defence Policy: Response to Unipolarity?" Security Studies 15, 2: 149-86.

Pratt, N. and S. Richter-Devroe (2011). "Critically Examining UNSCR 1325 on Women, Peace and Security." International Feminist Journal of Politics 13, 4: 489-503.

Puechguirbal, Nadine (2012). "The cost of ignoring gender in conflict and post-conflict situations: A feminist perspective." Amsterdam Law Forum 4, 1: 1-27.

Shepherd, Laura J. (2010). "Women, armed conflict and language-Gender, violence and discourse." International Review of the Red Cross 92, 877: 143-159.

Shepherd, Laura J. (2014). "Advancing the women, peace and security agenda: 2015 and beyond." NOREF Norwegian Peacebuilding Resource Centre. August 28.

Sjoberg, L. and C. Gentry (2007). Mothers, Monsters and Whores: Women's Violence in Global Politics. New York: Zed Books.

Spencer, Graham (2004). "Reporting Inclusivity: The Northern Ireland Women's Coalition, the News Media and the Northern Ireland Peace Process." Irish Journal of Sociology 13, 2: 43-65.

Stern, Maria (2011). "Gender and Race in the European Security Strategy: Europe as a 'force for good'?" Journal of International Relations and Development 14, 1: 28-59.

Teshome-Bahiru, Wondwosen (2009). "Electoral Violence in Africa: Experiences from Ethiopia." International Journal of Human and Social Sciences 3, 2: 176-201.

United Nations (2000). Security Council Resolution 1325: Women Peace and Security. New York: United Nations (s/Res/1325).

United Nations (2013). Security Council Resolution 2122: Women Peace and Security. New York: United Nations (s/Res/2122).

UN Women (2012). Women's Participation in Peace Negotiations: Connections between Presence and Influence. New York: UN Women.

Waylen, Georgina (2014). Understanding Institutional Change from a Gender Perspective. Manchester: Manchester University Press.

Woodward, Alison (2003). "Building velvet triangles: gender and informal governance," in T. Christiansen and S. Piattoni, editors, Informal Governance in the European Union. Cheltenham: Edward Elgar. 